\title{
HUBUNGAN POLA ASUH DAN TINGKAT KEMENDIRIAN PERSONAL HYGINE PADA SISWA KELAS 1 SEKOLAH DASAR NEGERI 21 GELUMBANG
}

\author{
Asih Fatriansari ${ }^{1}$, Rahmalia Afriyani ${ }^{2}$, \\ Program Studi Ilmu Keperawatan STIK Siti Khadijah \\ Email: asih.fatriansari13@gmail.com \\ rahmaliaapriyani@gmail.com
}

\begin{abstract}
ABSTRAK
Latar belakang : Salah satu perilaku yang dilakukan oleh orang tua adalah personal hygine. Perilaku ini lebih baik dimulai sedini mungkin, sebelum memasuki usia 3 tahun, akan terjadi efek jangka Panjang saat stimulasi pada usia ini terlambat diberikan seprti timbulnya kebiasaan mengompol hingga dewasa serta kebersihan diri sendiri yang tidak baik . Tujuan : Mengetahui hubungan antara pola asuh orang tua dengan kemandiraian personal hygiene siswa kelas 1 SDN 21 Gelumbang. Metode : Penelitian ini merupakan survey analitik dengan pendekatan krossektional, dilakukan pada tanggal 22 Juli 2019- 10 Juli 2019 di SDN 21 Gelumbang. Populasi pada penelitian ini adalah seluruh orang tua siswa kelas 1 berjumlah 56 orang responden sedangkan sampel didapat dengan tehnik total sampling. Analisis data yang digunakan adalah uji chi square. Hasil : Pola asuh orang tua secara sigifikan berhubungan dengan kemandirian personal hygiene pada siswa di SDN 21 Gelumbang p-value : 0.001 . Saran : Perlu dilakukan pendidikan kesehatan tentang pola asuh dan kemandirian personal hygiene.
\end{abstract}

\section{Kata Kunci : Pola Asuh, Kemandirian}

\begin{abstract}
Background : Personal hygiene was one of the behaviors carried out by parents. It was better to start this behavior as early as possible, before entering the age of 3 years, there will be longterm effects when stimulation at this age was given late, such as the emergence of bedwetting habits until adulthood and poor personal hygiene. Objective: To find out the relationship between parenting style and personal hygiene independence of grade 1 students at SDN 21 Gelumbang. Methods: This research is an analytical survey with a cross-sectional approach, conducted on July 22, 2019 - July 10, 2019 at SDN 21 Gelumbang. The population in this study were all parents of grade 1 students totaling 56 respondents while the sample was obtained by total sampling technique. Analysis of the data used is the chi square test. Result: Parenting was significantly related to personal hygiene independence in students at SDN 21 Gelumbang pvalue : 0.001. Suggestion: It is necessary to conduct health education about parenting and personal hygiene independence.
\end{abstract}

Keywords: Parenting, Independence 


\section{PENDAHULUAN}

Orang tua merupakan lingkungan paling dekat bagi seorang anak. Anak akan mempelajari dan meniru dan secara langsung ataupun tak langsung pola perilaku orang tuanya. Anak akan mencontoh kebiasaan, cara bertutur kata, bersikap, mengekspresikan perasaan, tuntutan serta mengkritik satu sama yang dilakukan oleh orang tuanya dengan baik akan berdampak baik untuk pertumbuhkembangan anaknya bahkan sebaliknya (Tridonanto, 2014).

Salah satu perilaku yang dilakukan oleh orang tua adalah personal hygine. Perilaku ini lebih baik dimulai sedini mungkin, sebelum memasuki usia 3 tahun, akan terjadi efek jangka Panjang saat stimulasi pada usia ini terlambat diberikan seprti timbulnya kebiasaan mengompol hingga dewasa serta kebersihan diri sendiri yang tidak baik (Titisari, 2015)

Saat ini terjadi fenomena dimana kurangnya kebersihan diri pada anak usia sekolah yang bermapak pada terjadinya penyakit akibat kebersihan diri yang tidak baik meliputi diare atau kecacingan. Lebih lanjut situasi ini disebabkan oleh ketidakmampuan seorang anak untuk melakukan kegiatan personal hygine yang masih dibantu oleh orang tua atau belum mandiri ( Vidya dan Mustikasari, 2018).

Kemandirian anak usia sekolah dalam melakukan personal hygine berhubungan dengan pola asuh orang tua ( Dewi, 2017). Sama halnya dengan hasil penelitian yang dilakukan oleh Lestari, (2019) pola asuh dengan kemandirian anak berhubungan secara signifikan dengan nilai $\mathrm{X} 2$ sebesar 11,335. Pola asuh anak secara authoritarian berkontribusi lebih kecil daripadi autoritaive. Lebih lanjut menurut Sari, dkk (2018) kemandirian personal hygiene dipengaruhi factor: stress, pengalaman, peran, tipe pola, keterlibatan orang tua.

Hasil observasi pada siwa kelas 1 di SDN 21 Gelumbang, menunjukan sebagian besar siswa masih ditunggui oleh orang tuanya hingga pulang sekolah. Wawancara singkat dengan orang tua siswa, 1 dari 5 orang tua siswa mengatakan bahwa anaknya masih suka mengompol, dan mandi pagi juga masih di bantu oleh ibu atau neneknya. Maka dari itu penulis tertarik untuk meneliti tentang hubungan pola asuh dengan kemandirian anak melakukan personal hygine pada siswa kelas 1 SD N 21 Gelumbang.

\section{METODE PENELITIAN}

Rancangan yang digunakan dalam penelitian ini adalah survey analitik dengan pendekatan kroseksional. Subjek penelitian ini adalah seluruh siswa pada kelas 1 SDN 21 Gelumbang pada tahun 2019 berjumlah 56 orang siswa. orang anak asuh dengan teknik pengambilan sampel menggunakan total sampling.

Instrumen yang digunakan adalah kuesioner pola asuh dan kemandirian personal hygine. Pengujian statistik penelitian ini menggunakan analisis chi, dengan kemaknaan hasil uji ditentukan berdasarkan nilai $p<0,05$.

Penelitian ini telah dilakukan pada tanggal 22 Juli 2019 - 10 Agustus 2019 di SDN 21 Gelumbang.

\section{HASIL}

\subsection{Analisis Univariat}

Distribusi frekuensi karakteristik responden pada penelitian ini terdapat pada Table 1. 
Tabel 1. Karakteristik Responden (n: 56)

\begin{tabular}{lll}
\hline Karakteristik & n & \% \\
\hline Pekerjaan & & \\
Bekerja & 24 & 42.9 \\
Tidak Bekerja & 32 & 57.1 \\
Usia & & \\
Muda & 39 & 69.6 \\
Tua & 17 & 30.4 \\
Pendidikam & & \\
Tinggi & 16 & 28.6 \\
Rendah & 40 & 71.4 \\
Pola Asuh & & \\
$\begin{array}{l}\text { Demokratif } \\
\text { Otoriter }\end{array}$ & 23 & 41.1 \\
Permisif & 19 & 33.9 \\
Kemandirian & 14 & 25.0 \\
Personal Hygien & & \\
Mandiri & & \\
Kurang Mandiri & 21 & 37.5 \\
Tidak Mandiri & 20 & 35.7 \\
\hline
\end{tabular}

Tabel 1 menunjukan bahwa dari 56 orang responden sebagain besar memiliki tidak berkerja $(57,1 \%)$, berusia muda $(69,9 \%)$, pendidikan rendah $(71,4 \%)$, pola asuh demokratif $(41,1 \%)$, mandiri dalam melakukan personal hygiene $(37,5 \%)$.

\subsection{Analisa Bivariat}

Analisis hubungan antara pola asuh dengan kemandirian personal hygiene anak SD N 21 Gelumbang terdapat pada table 2.

\section{Tabel 2. Hubungan Pola Asuh dengan Kemandirian Personal Hygiene Anak}

\begin{tabular}{|c|c|c|c|c|c|c|c|c|c|}
\hline \multirow{3}{*}{ Pola Asuh } & \multicolumn{6}{|c|}{ Kemandirian Personal Hygiene } & \multirow{2}{*}{\multicolumn{2}{|c|}{ Total }} & \multirow{3}{*}{$\mathrm{p}$-value } \\
\hline & \multicolumn{2}{|c|}{ Mandiri } & \multicolumn{2}{|c|}{ Kurang } & \multicolumn{2}{|c|}{ Tidak } & & & \\
\hline & $\mathrm{n}$ & $\%$ & $\mathrm{n}$ & $\%$ & $\mathbf{n}$ & $\%$ & $\mathbf{n}$ & $\%$ & \\
\hline Demokratif & 15 & 65.2 & 3 & 13.0 & 5 & 21.7 & 23 & 100 & \multirow{4}{*}{0,001} \\
\hline Otoriter & 5 & 26.3 & 7 & 36.8 & 7 & 36.8 & 19 & 100 & \\
\hline Permisif & 1 & 7.1 & 10 & 71.4 & 3 & 21.4 & 14 & 100 & \\
\hline Total & 21 & 37.5 & 20 & 35.7 & 15 & 26.8 & 56 & 100 & \\
\hline
\end{tabular}

Tabel. 2 menunjukan bahwa sebagian besar anak yang mendapat pola asuh demokratis mandiri dalam melakukan personal hygiene
( $65,2 \%$ ), sedangkan anak yang mendapat pola asuh otoriter lebih banyak kurang mandiri dalam melakukan personal hygiene $(36,8 \%)$, lebih lanjut anak yang mendapat permisif lebih banyak kurang mandiri personal hygiene $(71,4 \%)$. Hasil uji chi square didapat nilai $\mathrm{p}$ : 0,001 menunjukan bahwa terdapat hubungan yang signifikan antara pola asuh dengan kemandirian personal hygiene anak.

\section{PEMBAHASAN}

Hasil penelitian menjukan bahwa terdapat hubungan antara pola asuh orang tua dengan kemadirian personal hygine anak SD. Sebagian besar anak SD N 21 Gelumbang telah mandiri melakukan personal hygiene hal ini berhubungan dengan pola asuh yang diberikan oleh orang tuanya. Pola asuh demokratif yang memungkin anak untuk lebih mandiri dikarena pola asuh ini lebih menekan kepada kepentingan anak dan disisi lainny juga dapat mendisiplinkan anak tanpa raguragu, orang tua memberikan perintah sesuai dengan kemampuan anak, tanpa adanya paksaan. Orang tua memberikan penjelaskan akan aturan yang diterapkan untuk mendisiplinkan anak, senantiasa suportif terhadap keputusan anak dan membiarkan anak melakukan tugasnya secara mandiri.

Hasil penelitian ini sejalan dengan penelitian yang dilakukan oleh Putra (2012) terdapat hubungan antara pola asuh orang tua dan tingkat kemandirian anak, sebagian besar ibu menerapkan pola asuh demokratis $(80,8 \%)$ dan anaknya mencapai kemandirian dalam melakukan kegiatan personal hygiene.

Hasil penelitian ini juga sejalan dengan penelitian yang dilakukan oleh 
Vidya dan Mustikasari, (2018) adanya hubungan pola asuh dengan kemandirian personal hygiene anak disebabkan oleh penerapan pola asuh yang sesuai dalam hal pemberian kebebasan namun tetap harus di control sehingga anak dapat memiliki kemandirian yang baik sejak dini. Dengan kemandirian yang baik diharapkan anak dapat mengetahui tugas dan tanggung jawabnya.

Hasil penelitian ini didukung oleh teori yang dikemukan oleh Henri Nouwen dalam Judy et al (2012) menyatakan bahwa cara memaksa dan pengendalian pada anak tidak dapat menciptakan anak yang mandiri. Anak bukan produk, melainakan anugerah. Jika orang tua menerapkan metode tujuan untuk menciptakan jenis anak tertentu, untuk mengendalikan dan memaksa anak-anak untuk menjadi orang yang kita inginkan. Di lain sisi, saat orang tua merespon anak sebagai sebuah pemberian dan mengesampingkan pertahanan-pertahan sehingga mampu berinteraksi secara kreatif dengan mereka, ini akan memberikan hasil yang memuaskan membuat anak menjadi mandiri.

\section{KESIMPULAN}

Berdasarkan hasil analisis dan pembahasan diatas maka dapat disimpulkan bahwa terdapat pola asuh orang tua secara signifikan berhubungan dengan kemandirian anak SD N 21 Gelumbang.

\section{SARAN}

Perlu dilakukan penyuluhan kesehatan tentang pola asuh yang tepat dan sesuai untuk mendukung kemandiran anak dalam melakukan personal hygine.

\section{DAFTAR PUSTAKA}

Dewi, V. K. (2017). Hubungan Pola Asuh Orang Tua Dengan Tingkat Kemandirian Anak Retardasi Mental Ringan Di Sdlb Yplb Banjarmasin. An-Nadaa: Jurnal Kesehatan Masyarakat, 4(1), 21-25.

Judy et all. 2012. Sukses Membesarkan

Anak Dengan Pemberdayaan Hubungan. Alih Bahasa: Eddy Susanto. Tangerang: Kharisma Publishing Group.Lestari, M. (2019). Hubungan pola asuh orang tua dengan kemandirian anak. Jurnal Pendidikan Anak, 8(1), 84-90.

\section{Tridonanto, A. (2014). Mengembangkan} pola asuh demokratis. Elex Media Komputindo.

Sari, D. N. A., Safitri, N., Susilawati, S., \& Nasrullah, N. (2018). Faktor yang mempengaruhi pola asuh orang tua dalam kemandirian personal hygiene pada anak pra sekolah di Tk Islam Pelangi Anak Pandeyan Umbulharjo Yogyakarta. Riset Informasi Kesehatan, 7(1), 24-30

Titisari, L. Hubungan Dukungan

Keluarga Dengan Kemandirian Personal Hygiene Anak Prasekolah Di TK Aba. 2015.

Vidya, H., \& Mustikasari, S. (2018).

Hubungan Pola Asuh Orangtua Dengan Kemandirian Personal Hygiene Anak Usia Prasekolah Di Tkit Permata Mulia Desa Banjaragung Kecamatan Puri Kabupaten Mojokerto. Nurse and Health: Jurnal Keperawatan, 7(1), 51-60. 